\title{
Teaching Gases through Problem-based Learning
}

\author{
Mukadder Baran \\ Correspondence: Mukadder Baran, Hakkari University, Education Faculty, Hakkari, Turkey \\ Received: February 28, 2016 Accepted: March 23, 2016 Online Published: March 26, 2016 \\ doi:10.11114/jets.v4i4.1498 URL: http://dx.doi.org/10.11114/jets.v4i4.1498
}

\begin{abstract}
The purpose of this study was to investigate not only the applicability of the method of Problem-Based Learning (PBL) to the lesson subject of "Gasses" within the scope of the $9^{\text {th }}$ grade course of Chemistry in Hakkari Gazi High School but also the influence of this method on the students' achievement levels in chemistry and on their motivation and attitudes towards chemistry. For this purpose, the mixed method, which involves both quantitative and qualitative designs, was applied. In the study, the embedded design, one of the mixed methods of research, was used. The research sample included 56 students taking the course of Chemistry in Hakkâri Gazi High School. In the study, the students were divided into two groups: experimental group $(n=27)$ and control group $(n=29)$. The PBL method was applied to the experimental group. The application was carried out in the Spring Term of the academic year of 2014-2015. Before and after the application, an achievement test to measure the students' levels of success in the lesson subject of "Gasses", attitude scale towards chemistry, motivation scale for chemistry, scenario, reports and observation forms were used. As the study dominantly had a quantitative design, quantitative data collection tools were used. In order to support the quantitative data collection tools and to gather more detailed data, the observation method was also used as a data collection tool. For the analysis of the quantitative data, package software of SPSS 18 was used. As for the analysis of the observation data, content analysis was conducted. The results revealed a significant difference between the achievement levels of the experimental and control groups. However, no significant difference was found between the experimental and control groups regarding their motivation and attitudes. In the light of the observations recorded, it could be stated that the PBL method increased the students' intragroup and intergroup communication skills, their self-confidence and their skills in making presentations and reporting.
\end{abstract}

Keywords: problem- based learning, teaching, gases, chemistry

\section{Introduction}

Since time immemorial, the humankind has always been producing something, enabling societies to progress. Such progress is the product of productive societies, and the sustainability of this production depends on education because, in its most general sense, education refers to the transfer of the accumulated knowledge. However, this accumulated knowledge becomes heaps of information in time, the transfer of which has been one of the main problems of education. This has also become an unavoidable problem for the students who are responsible for learning it.

Although educators, or rather, the individuals who are responsible for teaching have been curious to find out how learning occurs, it was not until the 19th century that they began to carry out scientific research to satisfy that curiosity (Schunk, 2009, p.12). They proposed various learning theories. One of these theories is the social constructivist theory. Social constructivist theorists argue that a learner is not independent of his/her learning because the previous knowledge, social environment, language and culture play a vital role in the learning process. Thus, social constructivist theorists can be said to draw attention to the bridge between the learning and the learner. Thus, it can be said that such constructivist methods help learners to make the learning activity meaningful by focusing on their daily life, and their social/cultural environment.

One of the theories proposed by social constructivist theorists is Problem-based Learning (PBL). PBL was first applied in McMaster Medical School in the 1960s (Barrows, 1986). This learning approach was later used in many diverse fields such as medicine, natural sciences, engineering and law in many different countries (Boud \& Feletti, 1997).

PBL is a learner-centered approach whereby students learn how to study in small groups and try to describe or solve a complex problem selected from daily life (Elder, 2015). Problem-based Learning (PBL), a group-based learning approach, allows learners to take part in research and problem-solving activities to better understand the theoretical concepts and the practical relevance of the problem they want to solve (Mühlfelder, Konermann \& Borchard, 2015). In 
the PBL method, the learners have presented an issue from daily life to be solved. For older learners, this problem is presented in such a vague and "complicated" way that they do not have any clear way or procedure to follow. Typically, the learners work in small cooperative groups. The teacher or the assistant (tutor) mostly assume a facilitator role in the group discussions but do not guide or control the research process (Westwood, 2008, p. 31). PBL educators have important roles like motivating the learners, engage them in the lesson, help them express their arguments with their reasons, and support them in expressing their original ideas (de Grave, Dolmans \& van der Vleuten 1999, p 902 ).

Studies have revealed that PBL has a positive effect on learner skills. In relation to the most prominent benefits of PBL, it could be stated that the method increases students' ability to conduct research, integrates theory and practice, allows communication and group work, helps apply knowledge and skills to find an appropriate solution to a problem and develops self-directed studies (Dochy, Segers, Bosscher \& Gijbels., 2003; Hung, 2009; Lopes, Filho, Marsden \&Alves, 2011; Mamede, Schmidt, \& Norman, 2006; Rikers \& Bruim, 2006; Wood, 2003). However, there are such disadvantages of PBL as problems related to working in groups, individuals' not doing any preparations, establishing poor communication with each other, "having negative attitudes towards one another, experiencing potential problems with loafers not doing their share of the workload or with overly assertive members taking too much control, and having anxiety about collaborative learning experiences. Inexperienced teachers are likely to dominate and provide too much direction, and they potentially revert to didactic instruction, the role of the instructor and quality of the problem scenario" (Elder, 2015).

As a result of the meta-analysis conducted on PBL, it was found that the PBL approach has a positive effect on the attitudes of learners toward science courses compared to traditional teaching methods. Ayaz, 2015 found that PBL has positive effects on the learner attitudes toward science courses, and the PBL approach has a higher effect (positive effect) on students' academic achievement in chemistry.

Various studies have shown that learners have difficulty in understanding many subjects in chemistry courses, have problems in visualizing subjects in their minds and have conceptual misunderstandings regarding these subjects (Çalık \& Ayas, 2002; Karaçöp \& Doymuş, 2012; Piquette \& Heikkinen, 2005; Treagust, Chittleborough \& Mamiala, 2003). In the last 30 years or so, in related literature, there have been many reports on students' misconceptions, defined as any concept that is different from the widely accepted scientific understanding of the term (Nakhleh (1992), and difficulties with a variety of aspects of scientific reasoning (Grayson, Anderson, \& Crossley, 2001).

The subject of "gases" is one of the subjects that learners have a hard time learning (Doymuş, 2007; Hammar, 2013; Şahin \& Çepni, 2012). The most challenging chemistry subject for learners is the "gases." The biggest reason for this seems to be the fact that gas concepts are too abstract for them (Şenocak, 2005).

Many studies focusing on the subject of gases have found that employing multiple methods and techniques to teach it helps learners with this micro-level subject (Kaya, 2005; Ipek, 2007; Yeşiloğlu, 2007).

When the relevant literature is analyzed, learners are found to harbor misconceptions regarding gases (Griffiths and Preston, 1992; Kariper, 2013) and have difficulty learning the subject of gases since it is an abstract concept. So as to prevent learners from coming to class with inadequate knowledge, it seems crucial to design opportunities and materials that will interest them in the subject and allow them to think rationally. To this end, it may help to present problems in the learning environment by drawing from daily life familiar to the learners at this early stage of their academic lives, which can increase their interest and motivation to learn the subject of gases. Thus, through this present study, learners are expected to realize that the subject of gases is not just composed of abstract concepts and formulas, but rather a result of the events in many stages of their lives, and thus become logical and meaningful for them. This study seeks answers to the research questions below.

What is the applicability of the PBL method in the subject of "Gases" in the 9th-grade chemistry course taught at Hakkari Gazi High School, and what is the effect of this method on learners' success rates in chemistry, and on their attitudes and motivations toward chemistry?

1. What is the effect of PBL on students' academic achievement in chemistry?

2. What is the impact of PBL on students' attitude toward chemistry?

3. What is the effect of PBL on students' motivation for learning chemistry?

\section{Method}

\subsection{Research Design}

Including both quantitative and qualitative research designs, the mixed research method is used in this study to be able to answer the research questions, and as one of the mixed methods of research, the embedded design is used. 
The embedded design can be utilized when a qualitative component needs to be added to a heavily quantitative study, or a quantitative component needs to be included in a heavily qualitative study. In this design, compared to the primary data set, the secondary data set plays a supportive auxiliary role. Since different questions are answered and each question requires a different explanation, a single data collection set is not sufficient for this design. Embedded design comprises both qualitative and quantitative data. However, one type of data has an additional role within the scope of conception (Creswell and Plano-Clark, 2007). In this study, qualitative ( reports, worksheets paper, observations) and quantitative data (achievement test, questionnaire on motivation and attitude) were used. The qualitative data sets where used in a supportive role to find out students behavior, writing and reporting skills.

\subsection{Study Sample}

The sample for this study is composed of 56 Hakkari Gazi High School students taking a chemistry course, who are selected through convenience sampling. The implementation was conducted during the spring semester of the 2014-2015 academic year. But before applying PBL to that school, permission was taken from "National Education Directorate" of the city of Hakkari.

\subsection{Data Collection Tools}

The following data collection tools are used by taking the research questions into account.

1. Pre- and post- achievement tests to measure students' levels of achievement on the subject of "Gases."

2. Questionnaire on attitude toward chemistry

3. Questionnaire on motivation for chemistry

4. Implementation material (Scenario)

5. Course observation form

6. Worksheets and assignment reports

\subsection{Development and Implementation of the Data Collection Tools}

In this section, the scales (data collection tools) developed or adopted from other studies for this research are introduced.

\subsubsection{Development and Implementation of the Gases Academic Achievement Test (GAAT)}

For the present study, "Gases Academic Achievement Test" (GAAT) has been developed to analyze the effect of PBL on student achievement. For the development of the GAAT, considering the predetermined outcomes and the concepts for these findings, 27 multiple-choice questions were prepared. To what degree the developed test matched the results and whether the questions met the cognitive learning level in the revised taxonomy of Bloom (Krathwohl, 2002) were analyzed. The piloting for the achievement test was carried out in Hakkari with students $(n=107)$ who have just been taught the subject of "Gases". By assigning 1 point for each correct answer and 0 for each wrong respond to the achievement test was scored, and the item difficulty index and item discrimination index were determined first. As a result of the item analysis, item discrimination index for 5 questions was found to be lower than 0 , and therefore, these 5 questions were removed from the test. The reliability test conducted after the removal of these questions indicated that the reliability coefficient was 0.724 . In cases where Cronbach's Alpha value is 0.70 or higher, the scale is considered reliable (Sipahi, Yurtkoru and Çinko, 2008, s.89). Thus, GAAT can be said to be reliable.

\subsubsection{Attitudes towards Chemistry Questionnaire and Motivation in Chemistry Questionnaire}

The attitudes towards chemistry questionnaire used in this study was developed by Geban, Ertepinar, Yilmaz, Altin and Sahbaz (1994), it has 15 positive and negative 5-points Likert-type items ranging from strongly agree to disagree strongly. The items are generally like the following:

- Chemistry is my favourite lesson

- I generally spend time studying chemistry

- Chemistry isn `t important in my daily life

- I join chemistry lessons with pleasure

- I'd like to learn more issues on chemistry

- I get bored when I study chemistry

The motivation in chemistry questionnaire was developed by Glynn and Koballa (2006). It includes 22, 5-points Likert-type items (Never, Rarely, Sometimes, Usually, Always ) to measure students' motivation in chemistry. Such as: 
- I like to learn chemistry

- The subjects I'm learning in chemistry are related to my aim

- I want to be more successful than the other students in chemistry exams

- I’m worried when I think about chemistry exams

- I work hard to learn chemistry

- I hate chemistry

\subsubsection{Development and Implementation of the Application Material}

A scenario was developed by taking into account the concepts to be learned to achieve the predetermined outcomes for the "Gases" subject.

The application material was implemented with 15 10th grade students taking chemistry course in Hakkari High School. Firstly, the students were introduced to PBL and the procedure to which they are supposed to follow was explained to them. The students were handed out the achievement test course notes. The students were then divided into 5 groups. Each group was given the "Pepper gas and rising cake" scenario, and asked to discuss the scenario and answer the questions at the end of the scenario. Each student group answered the questions and presented them as a report. Students were also inquired about the intelligibility and applicability of the application material. The materials were then revised in the light of this piloting data. The final version of the application material is presented in Appendix A.

Before the prepared material was implemented in the experimental group, they were first given the necessary information on the application of PBL. The students were put into a total of 5 groups. The 1st Group was named "Koma Gel", 2nd Group was "Karincalar" (Ants), 3rd Group was "Chemists", 4th Group was "Forever", and the 5th Group was "Stars," making 4 groups of 5 , and 1 group of 6 . The application material was implemented as explained above.

\subsubsection{Observation Form}

Student observation forms were developed to analyze the effect of PBL on student participation, their ways of presenting and sharing information, and their interpersonal relationships and social skills in the classroom environment.

\subsection{Data Analysis}

Since this study is predominantly quantitative, quantitative data collection tools were used and to support the quantitative data collection tools and obtain more detailed data, observational data collection tools were used as well. SPSS 18 package program was used for the analysis of the quantitative data. As a method employed for the analysis of textual and visual data, content analysis was used for the analysis of the observational data. This method follows a deductive model. During the content analysis, the researcher first develops categories regarding the research topic, and then counts the words, sentences or images within these categories in the data set (Özdemir, 2010).

Table 1. Research Questions, Data Collection Tools and Data Analysis Methods

\begin{tabular}{|c|c|c|c|}
\hline Research Questions & Data Collection Tools & & Data Analysis Methods \\
\hline $\begin{array}{l}\text { 1. What is the effect of PBL on students' } \\
\text { academic achievement in chemistry? }\end{array}$ & - Gas Academic Achievement Te & st (GAAT). & - Inferential statistics \\
\hline $\begin{array}{l}\text { 3. What is the effect of PBL on students' } \\
\text { attitudes toward chemistry? }\end{array}$ & $\begin{array}{l}\text { - Attitudes toward Chemistry } \\
\text { (ACQ) } \\
\text { - Observations }\end{array}$ & Questionnaire & $\begin{array}{l}\text { - Inferential statistics } \\
\text { - Content analysis }\end{array}$ \\
\hline $\begin{array}{l}\text { 4. What is the effect of PBL on students' } \\
\text { motivation for learning chemistry? }\end{array}$ & $\begin{array}{l}\text { - Motivation in Chemistry } \\
\text { (MCQ) } \\
\text { - Observations }\end{array}$ & Questionnaire & $\begin{array}{l}\text { - Inferential statistics } \\
\text { - Content analysis }\end{array}$ \\
\hline
\end{tabular}

\section{Results}

\subsection{The Results from Gas Academic Test}

The maximum and minimum possible scores for the achievement test are 0 and 21 respectively. That is, a student answering all the question correctly on the test will score 21 , and the one answering all wrong will score 0 . The GAAT pretest results for the PBL experimental group and the control group show that the mean values of the groups are similar, and the groups are homogenous, as shown in Table 2. As it can be seen from the Table 2 the pre-test of the control group and the experimental group is very similar. It is similar because before applying this study, with the help of the subject teacher, two homogeneous classes where found (units of comparison being academic achievement and the students gender). The students were also administered post-tests, and the results were significant, favoring the experimental group. Table 1 shows that the average achievement score of the experimental group significantly increased while it dropped for the control group. As shown in Table 2 , there is a significant difference $(p<0,05)$ between the experimental group taught via PBL and the control group taught via traditional approach. At the same time while experimental group taught Gases through PBL the control group were taught the same subject via the traditional approach (teacher centered) by the same teacher in the experimental group. 
Table 2. Descriptive statistics of the achievement test

\begin{tabular}{llllll}
\hline ACHIEVEMENT & Groups & & Mean & $\begin{array}{l}\text { Std. } \\
\text { Deviation }\end{array}$ & Sig. (2-tailed) \\
\hline Pre-test & 1 & 27 & 7,5926 & 1,86587 &, 147 \\
& 2 & 29 & 6,7931 & 2,17747 &, 145 \\
Post test & 1 & 27 & 12,6296 & 3,06529 &, 000 \\
& 2 & 29 & 5,4828 & 2,45852 &, 000 \\
\hline
\end{tabular}

On the other hand as it can be seen from Table 2 control group post-test has dropped.

\subsection{The Results from Motivation and Attitude Questionnaire}

The analysis of the results from the chemistry motivation and attitudes pre-and post- tests on the experimental versus control group indicates that:

Table 3. Descriptive statistics of the motivation test

\begin{tabular}{lllll}
\hline MOTIVATION & Groups & Mean & Std. Deviation & Sig. (2-tailed) \\
\hline Pre-test & 1 & 81,3043 & 10,65336 &, 994 \\
& 2 & 81,2778 & 9,84471 &, 993 \\
Post test & 1 & 84,0435 & 12,24180 &, 094 \\
& 2 & 77,4444 & 12,15209 &, 094 \\
\hline
\end{tabular}

Table 4. Descriptive statistics of the attitude test

\begin{tabular}{lllcc}
\hline ATTITUDE & Groups & Mean & Std. Deviation & Sig. (2-tailed) \\
\hline Pre-test & 1 & 49,4783 & 5,70382 &, 521 \\
& 2 & 48,2778 & 6,12426 &, 525 \\
Post test & 1 & 50,0435 & 6,52602 &, 566 \\
& 2 & 48,7778 & 7,45619 &, 573 \\
\hline
\end{tabular}

The analysis of the statistical values on Table 3 and Table 4 do not indicate any significant difference between the pre and post motivation and attitude test scores.

\subsection{Assessment of Worksheets and Reports}

For the study, the worksheets used by Tatar (2007) were adopted to have the students answer the scenario questions. Through these worksheets, students were made to write down about what they knew, what they needed to know and how they would obtain the information they needed. Furthermore, the reports that they submitted at the end of their presentations were analyzed and their ways of solving the questions were determined.

During the analysis of the worksheets, as was the case in Tatar (2007), the scoring was as: 1 (weak), 2 (average) and 3 (adequate), the analysis was conducted by considering the following criteria:
$\checkmark$ Listing "what he/she knows" on the worksheet regarding the problem.
$\checkmark$ Listing "what he/she needs to know" on the worksheet regarding the problem.
$\checkmark$ Writing the ways to obtain the information.
$\checkmark \quad$ Table 5 below shows the scoring of worksheets and reports for each group.

Table 5. Scoring criteria for worksheets and reports

\begin{tabular}{rlc}
\hline 1. & $\begin{array}{l}\text { Itemizing what he/she knows for the solution of the } \\
\text { problem }\end{array}$ & 3 \\
2. Itemizing what needs to be researched for the solution & 2.3 \\
of the problem & 3 \\
3. $\begin{array}{l}\text { Writing how to obtain the necessary information } \\
\text { Presenting alternative solutions for the problem }\end{array}$ & 2 \\
\hline
\end{tabular}

\subsection{Findings Obtained from Observation Forms}

The student behaviors elicited through camera and semi-structured forms in the observed classroom are grouped under two main categories:

$\checkmark$ Intra-group and inter-group communication

$\checkmark$ Presentation and problem-solving

The results of the observations revealed the general student behaviors given in Table 6 . 
Table 6. Student Behaviors in Group Work

\begin{tabular}{rll}
\hline Behaviors & Frequency \\
\hline 1. & Reading the scenario aloud to the group & 6 \\
2. & Giving opinions on the problem & 24 \\
3. Listening to the group members & 27 \\
4. Discussing within group & 27 \\
5. $\quad$ Asking questions to the researcher & 6 \\
6. Objecting to the opinions of the group members & 5 \\
7. $\quad$ Agreeing with the opinions of the group members & 24 \\
8. Writing the worksheets & 6 \\
9. Using body language (eye contact, using hands, & 23 \\
10. Note taking & 6 \\
11. Moderating the group of voice...etc) & 6 \\
12. Being passive in the group & 5 \\
13. Presenting & 7 \\
\hline
\end{tabular}

The student behavior was observed via a camera and habits were found. It was seen that some students pretend to read something and stayed away from his/her group, some students were ambitious to solve the problems and some students visited other groups to find the solution of problems.

With the help of the scenarios handed out to the students, their intra- and inter-group behaviors were observed. These behaviors are presented in the tables below:

Table 7. Group Work Discussion

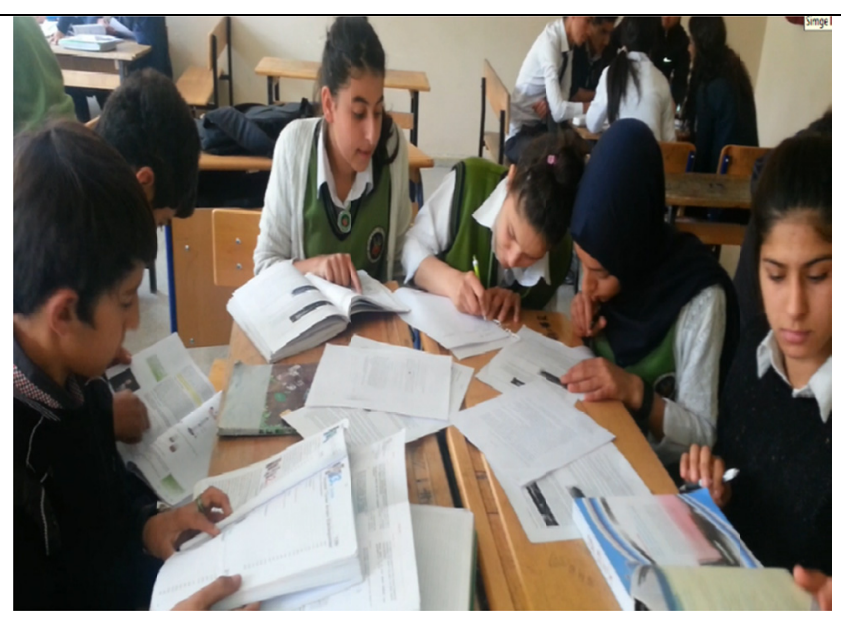

Scenario: Pepper gas and rising cake

\section{Group: Koma Gel Intra-group Discussion}

0:37-01:09

1. Groups discuss the Scenario.

2. S1 from Group Koma Gel reads aloud the Scenario

3. She comments on the Scenario

4. Agreeing with $\mathrm{S} 3$ and $\mathrm{S} 4, \mathrm{~S} 2$ and $\mathrm{S} 1$ and make additional remarks

5. S2 tries to write the pre-report according to S1's instructions.

6. S6 and S5 keep reading the Scenario and prefer to remain passive.

7. S6 thinks by looking at the source book.

\section{Dialogues:}

S1: In order to solve Question 3, factors that can change the volume will be researched

S5: I have found the answer for the question

S1: Boyle's Law, Avogadro's Law and Charles' Law will be written.

As can be seen in Table 7, S1 tries to explain the Scenario to the group. The group seems to have made a division of labor because it was observed that S3 was trying to write the pre-report by following the instructions by S1. S1 and S4 were found to listen to S1's comments and made their own comments. This can be said to indicate that the skills of intra-group information exchange, and the ability to transfer scientific information and sharing work aimed by PBL was successfully gained. On the other hand S5 and S6 preferred to stay passive and looked at their books to find answers. And it can be said that some students isolated themselves and tried to be individual, it can be shown as one of the shortcomings of PBL. 
In the implementation process of the PBL approach, the students presented the answers to the Scenario questions to their class. During this presentation, students in each group presented the scenario answers prepared by their own group before their classmates. The tables describing this situation are as follows:

Table 8. Presenting and Problem Solving

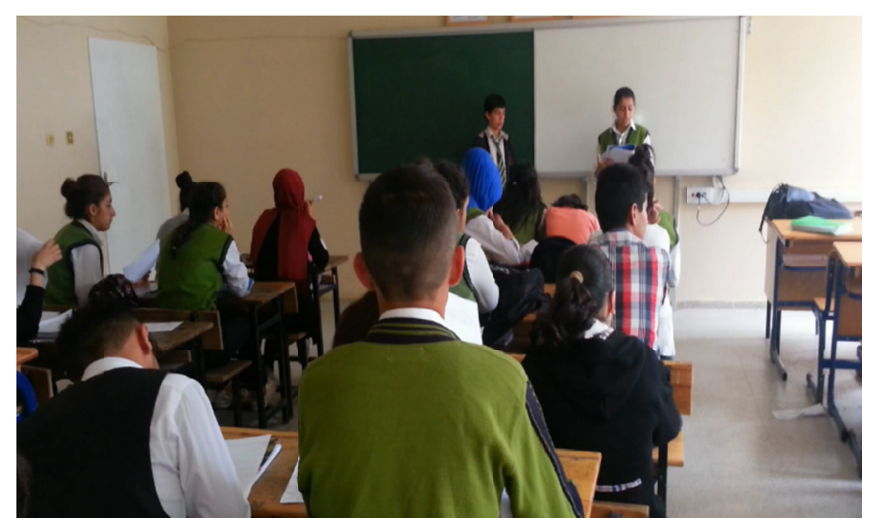

Scenario: Pepper gas and rising cake

Group: Karmcalar (Ants)

1.Question Presentation

01:50-02:17

1. Groups are listening to the presentation.

2. S12 and S13 give a presentation,

3. They make hand and eye contact. Asking questions to the classmates and making them think, they try to give the presentation. 3 . The classmates listen to them intently, the researcher intervenes at one point.

\section{Dialogues}

S12: Avogadro's Law defines these four variables like pressure, temperature, and amount of matter by complementing the Boyle's and Charles' Laws.

Researcher: Hey friends, what is Avogadro's number? (2 second wait) Avogadro makes you think of mole, doesn't it*

\section{Classroom: Yes}

S12: Mole is an amount as well, the higher the amount of a gas, the higher its volume is. If we are seeking an answer for the 1st question, as you know teacher, as it says in Boyle's Law, if a matter's volume increases in constant temperature its pressure decreases; if its pressure increases its volume decreases, that is, when one rises, the other drops.

Researcher: Which law was this?

Classroom: Boyle's law

It can be seen from Table 8 that S12 tries to explain the answer to the classroom. S13 helps S12 to write the gas laws formula on the board. S12 tries to make eye contact with her friends to make sure they listen her. While S12 and S13 explain the answers to the classroom, some students listen and some students take notes. The researcher tries to make students aware of the answer and asks them questions to help them think. It can be said that students could improve their presentation skills and improve their communication skills via PBL. 
Table 9. Problem Solving

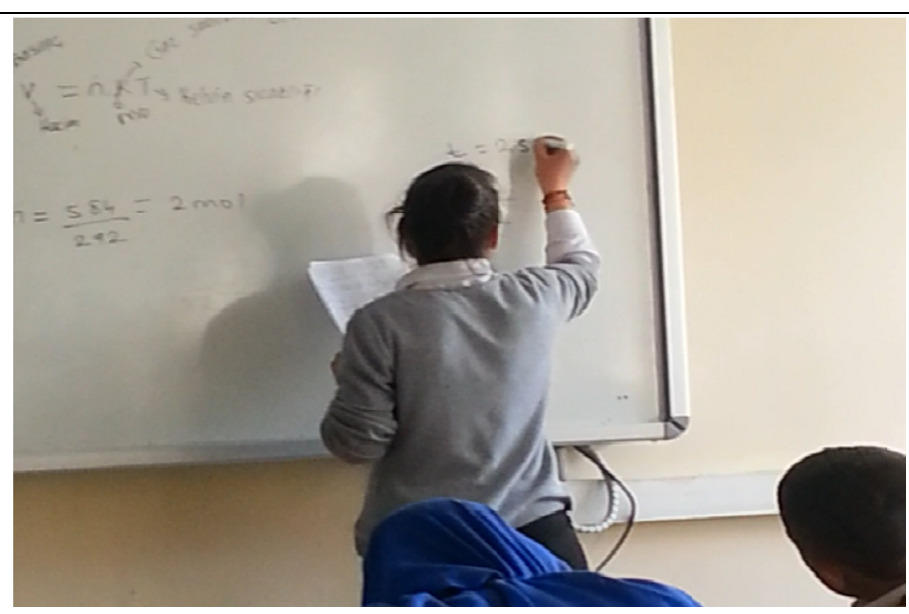

\author{
Scenario: Pepper gas and rising \\ cake
}

Group: Chemists

\title{
Problem Solution for Question 5 19:01-23:10
}

1. Groups are listening to the presentation.

2. Students are seeking the solution together.

3. S8 is trying to solve the problem with the help of the researcher.

4. S8 turns to other students and solves the problem with hand and eye gestures.

\section{Dialogues}

S7: If we divide 584 by 292, it equals two moles, Teacher, if the t temperature equaled 25 centigrade degrees,...

Researcher: How can we calculate it in Kelvin?

S7: 25 plus 273 gives it in Kelvin

S21: 25 or 23 ?

\section{S7: 25 degrees}

(S7 writes the definition of Boyle's law on the board as: Boyle's law= volume and pressure are inversely proportional.)

As can be seen in Table 9, the student gave their presentations both by problem-solving, and by explaining the answer to the class. This activity fits the constructivist philosophy in which students are active, and is observed that they have gained the skills of presenting, problem-solving, and inter-group communication.

It can be seen from the observations shown in Table 7, Table 8 and Table 9 students communicate with their group, perform presentations in the classroom, explain and solve the problems to their friends using eye contact and hands when they explain their ideas. It can be said PBL has given them the chance to use that ability and improve their abilities.

\section{Discussion and Conclusion}

When the findings from this study are analyzed, they are found to favor the experimental group as shown in Table 2 . This indicates that the PBL increases achievement more than the traditional method. The relevant literature also lends support to this conclusion (Baran, 2013; Crowley, 2015; Tasoglu \& Bakac, 2014; Vansconcelos, 2012; Y1ldiz, 2010; Zain, Samsudin \& Sale, 2014; Zejnilagic-Hajric, Sabeta, \& Nuic, 2015). PBL is related to the students real life, and in this study the scenario's context had been taken from real life situations in Hakkari. Because of the protests people are often exposed to pepper spray. It could be used as a method to help them solve pepper spray problems. On the other hand it can be seen from Table 2 that the control group mean has dropped. It can be said that the control group were aware that 'they were the control group ' and they think about 'why they are not involved with the experimental group', it can have a negative effect on their attitudes, motivation and on their achievement.

The questionnaire results given in Table 4 show that the PBL method does not have any effect on students' attitudes toward chemistry. The literature has similar studies where PBL has been found to have no effect on attitude (Özdil, 2011; Özkardeş-Tandoğan, 2006; Yıldız, 2010). No change in attitude can be explained by factors such as the relatively short 
period for implementation of the study, students' unfamiliarity with the method, not having a good student-teacher dialogue, and the fact that attitude is an affective quality that can only change over an extended period (Baran, 2013; Bukova, 2006; Kutu, 2011; Wijnia, Loyens, \& Derous, 2011). However, the literature review reveals that a majority of the research conducted on attitudes so far has found a positive effect of PBL on student attitudes (Gutwill-Wise, 2001; Liddle, 2000; Moralar, 2012; Overton, 2001).

The statistical findings (as shown in Table 3) demonstrate that PBL does not have any significant effect on students' chemistry motivation, which is supported by Galand, Bourgeois, and Frenay (2005). Also, in another study where PBL course was applied, the statistical analysis indicated that some students enjoyed this method while some others resisted changing their learning styles and did not like many aspects of PBL, like cooperative learning (Derry, Levin, Osana, Jonesve \& Peterson, 2000). In a similar vein, another recent study comparing PBL and conventional methods found that PBL could not always be seen to increase motivation (Wijnia, Loyens, \& Derous, 2011). Besides, conducting the present study in a very short time (3 weeks) can be given as another reason for the lack of change in motivation. However, when the literature is reviewed, PBL is found to increase student motivation for courses (Haruna, Yusof, Jamaludinc \& Hassan, 2013; Klegeris \& Hurren, 2011; Kutu, 2011).

The observation findings indicate that PBL help students to use their transferable skills, such as intra-group and inter-group communication, delivering presentations, problem-solving, reporting, and self-regulated learning. According to Norman and Schmidt (1992), PBL may increase knowledge retention, facilitate learning the new material by building on previous knowledge, increase student interest in the subject and can strengthen the students' self-learning skills. People may not be able to find other individuals to teach them how to do some certain things. Therefore, it is crucial for individuals to learn, early in their academic career, how to overcome a problem, what can be done in a particular situation and how to carry out research. Hence, using materials or applications to help them gain such self-learning skills is thought to be important.

As a result of their study in which they aimed to evaluate students' perceptions of PBL, De Wet and Walker (2013) found that most of the students prefer group work due to its facilitation of comprehension. Overall, the students reported that inter-group communication enables to have information exchange with the help of presentations and reciprocal question-answering, which is supported by the observations conducted so far. The visual recordings of the observations in the current study indicate that Intra- and inter-group communication occurs. Another benefit of group work is on learning. Since groups exchange information both within and across groups, they have higher chances of communicating with more knowledgeable group members, which may allow students with lower knowledge level to learn. Coca (2013) found that the group with which he used the cooperative method had a higher level of achievement.

One of the student assessment and evaluation methods in PBL is the oral presentation technique. The oral presentation also contributes to students' enhancement in their communication skills, expressing themselves clearly and articulately, transferring scientific information to their community, and indirectly to increasing their self-esteem. Many scientists assert that PBL improves oral presentation skill in various areas (Allen and Tanner, 2003; McGarvey, 2004; Kelly and Finalyson, 2007).

Reporting is an activity that students carry out by researching, analyzing, and presenting their findings in writing either individually or as a group. Whether notes are viewed as significant or not, the need for students to write reports becomes quite urgent at times. An effective assessment tool should also provide a complete and objective reporting skill for the student activity (Waters and McCracken, 1997). Reporting, that is, written communication skills is a skill that will be used by students throughout their lives, which has been found to improve with the help of PBL. Likewise, King (2009) found that students' writing skills improve through the application of PBL method. Furthermore, in the findings section of the present study, as can be seen in Table 4, where worksheets are scored, and research report assessment results are given, the high scores of the students can be taken as an indicator that PBL method can help students gain the reporting skill.

The observation findings of this study also identify some passive or uninterested students who are not engaged in the study. PBL may have some negative results besides its positive effects. Some of these potential drawbacks can be listed as remaining passive in the face of the dominant group members, inadequacy of the teacher in motivating the students, and failure of the scenario to provide sufficient motivation (Benbow and McMahon, 2001; Elder, 2015; Vardi \& Ciccarelli 2008; Wells, Warelow \& Jackson 2009). In a study carried out by Woods, Hall, Eyles, Hrymak and DuncanHewitt (1996), it was found that it was challenging to deal with dominant group members both in tutorials PBL groups and PBL groups with a tutor. If there is a tutor in group meetings, he or she can help other students deal with the dominating students in a constructive manner, yet it might be quite challenging for the tutor (Kinnunen \& Malmi, 2005 ).

In order for an individual to be free, he/she must be able to overcome his/her problems single-handedly. Such an 
individual who can solve his/her problems on his/her own is an individual that has achieved self-regulated learning and thus has taken the first step toward becoming a successful scientist with a high self-esteem. PBL is a pedagogical method that give the students chance to practice their potentials such as problem solving, presenting skills, reporting, communicating, learning independent ... etc. As such PBL can therefore be recommended for other subjects withın chemistry and other subjects.

\section{References}

Allen, D., \& Tanner, K. (2003). Approaches to cell biology teaching: learning content in contex Problem-Based Learning, Cell Biology Education, 2, 73-81. http://dx.doi.org/10.1187/cbe.03-04-0019

Ayaz, M. F. (2015). The effect of the problem-based learning approach on the academic achievements of the students in science lesson: a study of metaanalysis. International Periodical for the Languages, Literature and History of Turkish or Turkic, 10 (3), 139-160.

Aziz, M. S., Zain, A. N. M., Samsudin, M. A., \& Saleh, S. (2014). The effects of Problem Based Learning on Self Directed Learning Skills among Physics Undergraduates. International Journal of Academic Research in Progressive Education and Development, 3(1), 126-137. http://dx.doi.org/10.6007/IJARPED/v3-i1/694

Baran, M. (2013). Yaşam temelli probleme dayalı öğretim yönteminin termodinamik konusunun öğretimine etkisi. Yayınlanmamış Doktora Tezi. Atatürk Ünivesitesi Eğitim Bilimleri Enstitüsü,Erzurum- Turkey

Barrows, H. S. (1986). A taxonomy of problem-based learning methods, Medical Education, 20, 481-486. http://dx.doi.org/10.1111/j.1365-2923.1986.tb01386.x

Benbow, E. W., \& McMahon, R. F. T. (2001) Mature students?, in: P. Schwartz, S. Mennin \& G. Webb (Eds) Problem-based Learning: Case Studies, Experience and Practice, pp. 119-125 (London: Kogan Page)

Boud, D., \& Feletti, G. I. (1997). The challenge of problem based learning. London: Kogan Page Ltd.

Bukova, E. (2006). Öğrencilerin limit kavramını algılamasında ve diğer kavramları ilişkilendirilmesinde karşılaştıkları güçlükleri ortadan kaldıracak yeni bir program gelişstirme. Yayınlanmamış Doktora Tezi, Dokuz Eylül Üniversitesi Eğitim Bilimleri Enstitüsü, İzmir.

Çalık, M., \& Ayas. (2002). Öğrencilerin bazı kimya kavramlarını anlama seviyelerinin karşılaştırılması. I. Öğrenme ve Öğretme Sempozyumu. Marmara Üniversitesi: İstanbul.

Coca, D. M. (2013).The influence of teaching methodologies in the learning of thermodynamics in secondary education. Journal of Baltic Science Education, 12 (1), 59-72.

Creswell, J. W., \& Plano-Clark, V. L. (2007). Designing and Conducting Mixed Methods Research. Thousand Oaks, CA: Sage Publication.

Crowley, B. M. (2015). The effects of problem-based learning on mathematics achievement of elementary students across time. A Specialist Project Presented to The Faculty of the Department of Psychology Western Kentucky University Bowling Green, Kentucky.

De Grave, W. S., Dolmans, D. H. J. M., \& van der, V. C. P. M. (1999). Profiles of effective tutors in problem-based learning: scaffolding student learning. Medical Education. 33, 901-906. http://dx.doi.org/10.1046/j.1365-2923.1999.00492.x

De Wet, L., \&Walker, S. (2013). Student perceptions of problem-based learning: A case study of undergraduate applied agrometeorology. ISRN Education, Article ID 982942, 9 pages. http://dx.doi.org/10.1155/2013/982942

Derry, S. J., Levin, J. R., Osana, H. P., Jones, M. S., \& Peterson, M. (2000). Fostering students' statistical and scientific thinking: Lessons learned from an innovative college course. American Educational Research Journal, 37, 747773. http://dx.doi.org/10.3102/00028312037003747

Dochy, F., Segers, M., Bossche, P. V., \& Gijbels, D. (2003). Effects of PBL: A Meta- Analysis. . Learnin and Instruction, 13, 533-568. http://dx.doi.org/10.1016/S0959-4752(02)00025-7

Doymuş, K. (2007). The effect of a cooperative learning strategy in the teaching of phase and one-component phase diagrams. Journal of Chemical Education, 84(11), 1857-1860. http://dx.doi.org/10.1021/ed084p1857

Elder, A. D. (2015). Using a Brief Form of Problem-Based Learning in a Research Methods Class: Perspectives of Instructor and Students. Journal of University Teaching \& Learning Practice, 12(1).

Galand, B., Bourgeois, E., \& Frenay, M. (2005). The impact of a PBL curriculum on students' motivation and 
self-regulation.

http://www.youscribe.com/catalogue/rapports-et-theses/savoirs/sciences-humaines-et-sociales/the-impact-of-a-pblcurriculum-on-students-motivation-and-1600703 [10 Aralık 2012].

Geban, Ö., Ertepınar, H., Yılmaz, G., Altın, A., \& Sahbaz, F. (1994). Bilgisayar destekli eğitimin öğrencilerin fen bilgisi başarılarına ve fen bilgisi ilgilerine etkisi [Influence of computer-aided education on students' achievements in science and on their interest in science], I. Ulusal Fen Bilimleri Eğitimi Sempozyumu: Bildiri Özetleri Kitabl [Proceedings of 1st National Symposium on Science Teaching], 1-2, Dokuz Eylül University, İzmir, Turkey.

Glynn, M. S., \& Koballa, T. R. (2006). Motivation tolearn college science. In J.J. Mintzes \& W. H. Leonard(Eds.), Handbook of college science teaching (pp. 25-32). Arlington, VA: National Science Teachers Association Press.

Grayson, D. J., Anderson, T. R., \& Crossley, L., G. (2001). A four level framewotk for identifying and classifying stundet conceptual and reasoning difficulties. International Journal of Science Education, 23, 611-622. http://dx.doi.org/10.1080/09500690119103

Griffiths, A. K., \& Preston, K. R. (1992). Grade 12- Students' misconceptions relating to fundamental characteristics of Atoms and Molecules. Journal of Research and Science Teaching, 29, 611-628. http://dx.doi.org/10.1002/tea.3660290609

GutWill-Wise, J. P. (2001). The impact of active and context based learning in introductory chemistry courses: An early evaluation of the modular approach. Journal of Chemical Education, 78(5), 684-690. http://dx.doi.org/10.1021/ed078p684

Hammar, M. (2013). Teaching the gas properties and gas laws: an inquiry unit with alternative assessment. Unpublished master thesis, Department of Cognitive and Learning Sciences Michigan Technological University

Harun, N. F., Yusof, K. M., Jamaludin, M. Z., \& Hassan, S. A. H. S. (2012). Motivation in Problem-based Learning Implementation. Procedia - Social and Behavioral Sciences, 56, 233-242. http://dx.doi.org/10.1016/j.sbspro.2012.09.650

Hmelo-Silver, C. E. (2004). Problem-Based Learning: What and How Do Students Learning? Educational Psychology Review, 16(3), 235-265. http://dx.doi.org/10.1023/B:EDPR.0000034022.16470.f3.

Ipek, I. (2007). Basit araçlarla öğrenmeye dayalı kavramsal değişim metodunun 10. Sınıfta gazlar konusunda uygulanması. Yayınlanmamış Yüksek Lisans Tezi, O.D.T.Ü Fen Bilimleri, Ankara.

Karaçöp, A., \& Doymuş, K. (2012). Effects of jigsaw cooperative learning and animation techniques on students' understanding of chemical bonding and their conceptions of the particulate nature of matter. Journal of Science Education Technology, 22, 186-203. http://dx.doi.org/10.1007/s10956-012-9385-9

Kariper, I. A. (2013). Fen Bilgisi Öğretmen Adaylarının Gazlar Konusundaki Kavram Yanılgıları. Journal of European Education, 3 (1), 33-35.

Kaya, Ö. (2005). Kimya eğitiminde yapılandırıcı yaklaşım ile geleneksel yaklaşımın karşılaştırılması. Yayınlanmamış Yüksek Lisans Tezi, Hacettepe Üniversitesi Fen Bilimleri Enstitüsü, Ankara.

Kelly, O. C., \& Finlayson, O. E. (2007). Providing solutions through problem-based learning for the undergraduate 1st year chemistry laboratory. Chemistry Education Research and Practice, 8(3), 347-361. http://dx.doi.org/10.1039/B7RP90009K

King, D. T. (2009). Teaching and learning in a context based chemistry classroom. Doktora tezi, Queensland University of Technology.

Kinnunen, P., \& Malmi, L. (2005). Problems in Problem-Based Learning - Experiences, Analysis and Lessons Learned on an Introductory Programming Course. Informatics in Education, 4(2), 193-214.

Klegeris, A., \& Hurren, H. (2011). Impact of problem-based learning in a large classroom setting: Student perception and problem solving skills. Advances in Physiology Education, 35, 408-415.

http://dx.doi.org/10.1152/advan.00046.2011

Koc, Y. (2014). Science students' understanding level of gases topic at micro level. Kafkas Eğitim Araştırmaları Dergisi, $1(1), 40-48$.

Krathwohl, D. R. (2002) A revision of Bloom's taxonomy: An overview. Theory into Practice, 41(4), 212-218. http://dx.doi.org/10.1207/s15430421tip4104_2 
Kutu, H. (2011). Yaşam temelli arcs öğretim modeliyle 9. sinıf kimya dersi "hayatımızdakimya" ünitesinin ögretimi. Yayınlanmamış doktora tezi, Atatürk Üniversitesi, Eğitim Bilimleri Enstitüsü, Erzurum.

Liddle, M. (2000). Student Attitudes Toward Problem-Based Learning in Law. Journal on Excellence in College Teaching, 11(2). [online] available from [17 June 2015]

Lopes, R. M., Filho, M. V. S., Marsden, M., \& Alves, N. G. (2011). Aprendizagem baseada em problemas: Uma experiência no ensino da química toxicológica. Química Nova, 34, 1275-1280. http://dx.doi.org/10.1590/S0100-40422011000700029

Mamede, S., Schmidt, H. G., \& Normam, G. R. (2006). Innovations in Problem-Based Learning: What Can We Learn from Recent Studies. Advances in Health Sciences Education, 11, 403-422. http://dx.doi.org/10.1007/s10459-006-9018-2.

McGarvey D. J. (2004). Experimenting with undergraduate practicals, University Chemistry Education, 8, 58-65.

Moralar, A. (2012). Fen eğitiminde probleme dayalı öğrenme yaklaşımının akademik başarı, tutum ve motivasyona etkisi. Yayınlanmamış yüksek lisans tezi. Trakya Üniversitesi, Eğitim Bilimleri Enstitüsü.

Mühlfelder, M., Konermann, T., \& Borchard, L. M. (2015). Design, Implementation, and Evaluation of a Tutor Training for Problem Based Learning in Undergraduate Psychology Courses. Journal of Problem based Learning in Higher Education, 3(2), 37-61.

Nakhleh, M. (1992). Why Some Students Don't Learn Chemistry: Chemical Misconceptions, Journal of Chemical Education, 69(3), 191-196. http://dx.doi.org/10.1021/ed069p191

Norman, G. R., \& Schmidt, H. G. (1992). The psychological basis of problem-based learning: A review of the evidence. Academic Medicine, 67(9), 557-565. http://dx.doi.org/10.1097/00001888-199209000-00002

Overton, T. L. (2001). Problem based learning: An introduction, LTSN Physical Sciences Primer 4, version 1, http://dbweb.liv.ac.uk/ltsnpsc/primers/intrpbl4.htm [12.08.2015].

Özdil, G. (2011). Probleme dayalı öğrenme yaklaşımının ilköğretim 7. sinıflarda çevre ve alan kavramı öğretiminde ögrenci başarısına etkisi.Yayınlanmamış yüksek lisans tezi. Kastamonu Üniversitesi, Fen Bilimleri Enstitüsü

Özkardeş, T. R. (2010). Fen eğitiminde probleme dayalı aktif öğrenmenin öğrencilerin başarılarına ve kavram ögrenmelerine etkisi. Yayınlanmamış yüksek lisans tezi. Marmara Üniversitesi, Eğitim Bilimleri Enstitüsü.

Piquette, J. S., \& Heikkinen, H. W. (2005). Strategies reported used by instructors to address student alternate conceptions in chemical equilibrium. Journal of Research in Science Teaching, 42(10), 1112-1134. http://dx.doi.org/10.1002/tea.20091

Rikers, R. M. J. P., \& Bruim, A. B. H. (2006). Introduction to the Special Issue on Innovations in Problem-Based Learning. Advances in Health Science Education, 11, 315-319. http://dx.doi.org/10.1007/s10459-006-9011-9

Şahin, Ç., \& Çepni, S. (2012). 5E öğretim modeline dayalı öğretimin öğrencilerin gaz basıncı ile ilgili kavramsal anlamalarına etkisi. Necatibey Ĕgitim Fakültesi Elektronik Fen ve Matematik Eğitimi Dergisi, 6(1), 220- 264.

Schunk, D. H. (2009). Öğrenme teorileri eğitimsel bir bakışla (5.Baskı). (M. Şahin, Çev.). Ankara: Nobel Yayın Dağııım. (Orjinal çalışma basım tarihi 1991).

Şenocak, E. (2005). Probleme dayalı öğrenme yaklaşımının maddenin gaz hali konusunun öğretimi üzerine bir araştırma. Yayınlanmamış Doktora Tezi, Atatürk Üniversitesi, Fen Bilimleri Enstitüsü, Erzurum.

Sipahi, B., Yurtkoru, E. S., \& Çinko, M. (2008). Sosyal bilimlerde SPSS'le veri analizi. İstanbul: Beta Basım Yayım Dağıtım

Tasoglu, A., K., \& Bakac, M. (2014). The Effect of Problem Based Learning Approach on Conceptual Understanding in Teaching of Magnetism Topics. Euroasian Journal of Physics and Chemistry Education, 6(2), 110-122.

Tatar, E. (2007). Probleme dayall ögrrenme yaklaşımının termodinamiğin birinci kanununu anlamaya etkisi. Yayınlanmamış doktora tezi. Atatürk Üniversitesi, Fen Bilimleri Enstitüsü.

Treagust, D., Chittleborough, G., \& Mamiala, T. (2003). The role of sub-microscopic and symbolic representations in chemical explanations. International Journal of Science Education, 25(11), 1353-1368. http://dx.doi.org/10.1080/0950069032000070306

Vardi, I., \& Ciccarelli, M. (2008). Overcoming problems in problem-based learning: a trial of strategies in an undergraduate unit. Innovations in Education and Teaching International, 45(4), 345-354.

http://dx.doi.org/10.1080/14703290802377190 
Vasconcelos, C. (2012). Teaching Environmental Education through PBL: Evaluation of a Teaching Intervention. Program. Research in Science Education, 42(2), 219-232. http://dx.doi.org/10.1007/s11165-010-9192-3

Waters, R, \& McCracken, M. (n.d.). Assessment and evaluation in problem based learning. Retrieved from http://peoplelearn.homestead.com/assess.pdf on 7.1.2015

Wells, S. H., Warelow, P. J., \& Jackson, K. L. (2009). Problem based learning (PBL): a conundrum. Contemporary Nurse, 33(2), 191-201. http://dx.doi.org/10.5172/conu.2009.33.2.191

Westwood, P. (2008). What teachers need to know about teaching methods. Camberwell Victoria: ACER Press.

Wheeldon, R., Atkinson, R., Dawes, A., \& Levinson, R. (2012). Do high school chemistry examinations inhibit deeper level understanding of dynamic reversible chemical reactions? Research in Science \& Technological Education, 30(2), 107-130. http://dx.doi.org/10.1080/02635143.2012.692362

Wijnia, A., Loyens, S. M. M., \& Derous, E. (2011). Investigating effects of problem-based versus lecture-based learning environments on student motivation. Contemporary Educational Psychology, 36(2), 101-113. http://dx.doi.org/10.1016/j.cedpsych.2010.11.00

Wood, D. F. (2003). ABC of Learning and Teaching in Medicine: Problem Based Learning. British Medical Journal, 326, 328-330. http://dx.doi.org/10.1136/bmj.326.7384.328

Woods, D. R., Duncan-Hewitt, W. C., Hall, F. L., Eyles, C. H., \& Hrymak, A. N. (1996). Tutored versus tutorless groups in problem-based learning. Am J Pharm Educ., 60(3), 231-238.

Yeşiloğlu, S. N. (2007). Gazlar konusunun lise öğrencilerine bilimsel tartı̧̧ma (argümantasyon) odaklı yöntem ile öğretimi. Yayınlanmamış doktora tezi. Gazi Üniversitesi Eğitim Bilimleri Enstitüsü, Ankara

Yıldız, N. (2010). Fen eğitiminde probleme dayalı öğrenme senaryolarının çözümünde deney uygulamalarının ögrencilerin başarısına, tutumuna ve bilimsel süreç becerilerine etkisi. Yayınlanmamış doktora tezi. Marmara Üniversitesi, Eğitim Bilimleri Enstitüsü.

Zejnilagić-Hajrić, M. A., Šabeta, A., \& Nuić, I. (2015). The effects of problem-based learning on students' achievements in primary school chemistry. Bulletin of the Chemists and Technologists of Bosnia and Herzegovina, 44, 17-22.

\section{Appendix A}

\section{Scenario Pepper Gas and Rising Cake}

\section{Pepper Gas and Rising Cake}

On a cold day, walking home from school, Fatma comes across a street protest. Security forces have just used pepper gas to disperse the activist crowd.

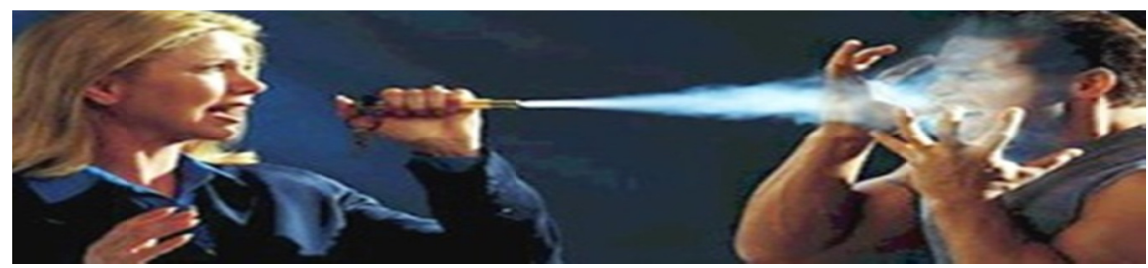

Irritated by the gas first in her throat and then her eyes, Fatma asks a person nearby to squeeze some lemon in her eyes. Her eyes now covered with lemon juice, Fatma rushes home. Since her home is very close to the location of the protest the pepper gas has filled certain parts of the home, except for the back rooms. Luckily, Fatma's room is one of the back rooms. When Fatma comes home, her mom, being used to this situation is making a cake in the kitchen. Fatma greets her mom, and quickly goes to her room, and taking a deep breath she thinks "Thank God it is cold, if it were hot, the pepper gas could reach all the way to my room".

Fatma stays in her room until the pepper gas wears off. However, she cannot resist the smell of the cake baking in the kitchen and goes to the kitchen. No trace of smell remains of the pepper gas in the kitchen. She sees a huge plate of rising cake on the kitchen counter. 


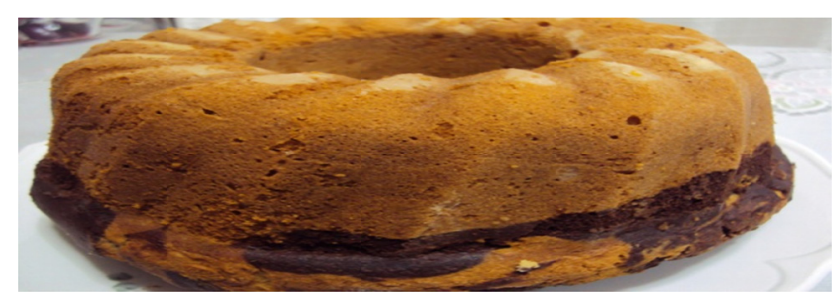

She asks her mom: "How can you make such a high-rising cake with such little dough?" Her mom says that she has used baking soda for that. Getting more curious, Fatma takes a slice of cake and goes back to her room, beginning to think about the rising (leavening) mechanism of the cake.

1) Explain the spraying and diffusion phenomena of the pepper gas mentioned above with gas laws (Boyle's law, Charles' law and Gay-Lussac's law).

2) Find the volume and amount of 0,25 mole pepper gas under normal circumstances (UNC). The formula of the pepper gas is $\mathrm{C}_{10} \mathrm{H}_{5} \mathrm{CIN}_{2}$ (The atom weights of the elements are respectively: $12 \mathrm{gr} / \mathrm{mole}, \mathrm{H}: 1 \mathrm{gr} / \mathrm{mole}, \mathrm{I}: 127$ $\mathrm{gr} / \mathrm{mole}, \mathrm{N}: 14 \mathrm{gr} / \mathrm{mole})$

3) To which gas law is Fatma's sentence "Thank God it is cold, if it were hot, the pepper gas could reach all the way to my room" related?

4) When the volume of 584 gr pepper gas at $25{ }^{\circ} \mathrm{C}$ is reduced to half under $10 \mathrm{~atm}$ pressure, what atm will its pressure be?

5) Which methods are necessary to differentiate the pepper gas from the other gases in the atmosphere?

6) Explain the factors that affect the diffusion and velocity of diffusion of gases.

7) Which of the events mentioned above are related to diffusion of gases?

8) Write down the reactions that cause the cake rise. Explain as a result of which laws the resulting gas causes the cake to rise.

9) If all the gases were ideal, what kind of problems would we encounter in the world (What are the ideal gases and how do they behave?)

10) Give examples from daily life resulting from the compression and expansion of gases.

11) Explain the proportional relation between the increase or diffusion or volume of pepper gas by using the gas law. 